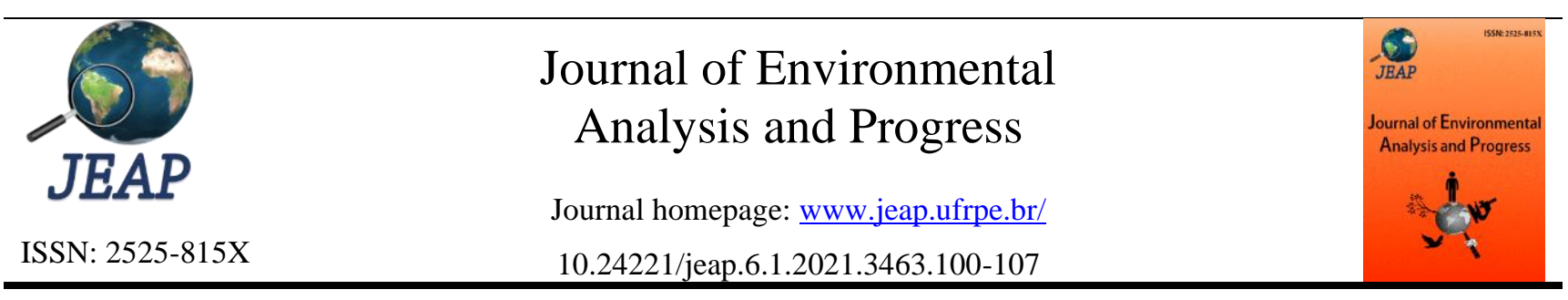

\title{
Piptadenia moniliformis Benth. seeds subjected to accelerated aging
}

\author{
Gilvaneide Alves de Azerêdo ${ }^{\mathrm{a}}$, Rinaldo Cesar de Paula ${ }^{\mathrm{b}}$
}

a Universidade Federal da Paraíba-UFPB, Centro de Ciências Humanas, Sociais e Agrárias, Departamento de Agricultura. Rua João Pessoa, s/n, Bananeiras, Paraíba, Brasil. CEP: 58.220-000. E-mail: azeredogil@ yahoo.com.br*.

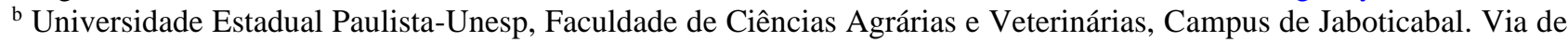
acesso Prof. Paulo Donato Castellane, s/n, Jaboticabal, São Paulo, Brasil. CEP: 14.884-900. E-mail: rinaldo.paula@unesp.br.

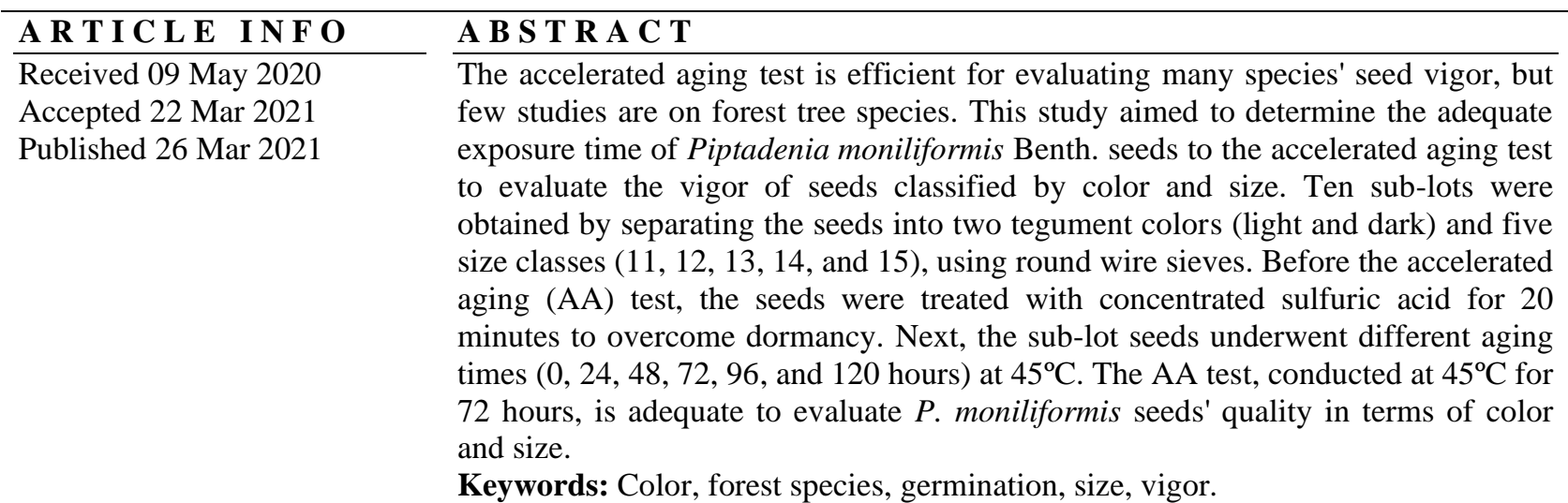

\section{Introduction}

The accelerated aging (AA) test is one of the most common vigor tests to assess seeds' physiological quality. It consists of exposing seeds to high temperatures and relative humidity, the main factors involved in the process, generating a high respiration rate and consuming much of their reserves, and accelerating the metabolic processes that lead to their deterioration (Marcos Filho, 2015). Thus, the AA test accelerates the natural aging of seeds (Delouche \& Baskin, 1973).

Seed vigor is defined by AOSA (1983) as one of the seed properties that determine its potential for rapid and uniform emergence under different environmental conditions, with the capacity to develop healthy seedlings.

The accelerated aging test is efficient in assessing quality differences between seed lots with similar germination, ranking them by quality levels. It also creates stress conditions for seeds and is efficient in evaluating their resistance to these adverse conditions, resulting in less and slower germination and a rise in abnormal seedlings (Marcos Filho, 2015).

In recent decades, researchers have focused on determining the quality of a seed lot, given that one of the objectives of vigor tests is to provide information about the ability of one or more seed lots to excel in the field when exposed to adverse conditions. Thus, the AA test can identify the best performing batches in field due to its properties.

Given that high-quality seeds are a prerequisite for obtaining vigorous and uniform seedlings, impacting the yield and quality of the harvested product, it is essential to have accurate information to evaluate them.

In the accelerated aging test, less vigorous seeds show a pronounced decline in viability, unlike their more vigorous counterparts, which maintain higher viability and the capacity to produce healthy seedlings (Marcos Filho, 2015). Due to the ease of application and interpretation of its results, several researchers involved with forest seeds have adopted this test, obtaining good results, as observed in studies carried out by several authors on different species (Padilha et al., 2018; Carvalho et al., 2016; Aquino et al., 2018; Araujo et al., 2017; Lima et al., 2014; Guareschi et al., 2015). Piptadenia moniliformis is a species belonging to the family Fabaceae and the Caatinga biome. It is highly valued for beekeeping, and being indicated for soil recovery, 
combating soil erosion, and for the first phase of forest restoration. It also helps in the growth of other species, including F1-grade (high quality) trees. This species has a twisted trunk with thin, rough bark, bipinnately compound leaves, and flowers arranged on cylindrical spikes. Its $13 \mathrm{~cm}$ long brown fruit is a flat pod that opens on only one side, exposing its oval white seeds (Maia, 2004).

The AA test is standardized to classify seed vigor for several agricultural species but is practically unknown for forest species such as $P$. moniliformis.

There are few tree seed studies involving vigor tests, such as accelerated aging. Only one study on P. moniliformis was found, but it did not consider seed size and color. As such, the present study was carried out to evaluate the effect of exposing $P$. moniliformis seeds to different accelerated aging times at $45^{\circ} \mathrm{C}$ on seed vigor classified according to color and size.

\section{Material and Methods}

This study was carried out in the Seed and Forest Improvement Laboratory of UNESP/Jaboticabal-SP, Brazil. The Piptadenia moniliformis Benth. seeds were collected from at least 15 mother trees located in the municipality of Campo Grande do Piauí, Piauí (PI) state and sent to UNESP/Jaboticabal, where they were stored in plastic packages in a cold chamber $(8 \pm$ $2^{\circ} \mathrm{C}, 60 \pm 5 \%$ relative humidity), until the experiment was conducted.

Given the presence of seeds with different colors and sizes, the batch was initially separated by integument color (C - light; D - dark) and classified into five size classes in round sieves $(\mathrm{P})$, corresponding to sizes $11,12,13,14$ and 15 , thereby constituting 10 sub-batches: S11L, S11D, S12L, S12D, S13L, S13D, S14L, S14D, S15L, and S15D.

Before the accelerated aging test, the seeds were scarified with concentrated sulfuric acid for 20 minutes (Azeredo et al., 2010), rinsed in running water for five minutes, and placed on paper sheets for three days.

Accelerated aging test (AA): The AA test was conducted at $45^{\circ} \mathrm{C}$ with four replicates of 25 seeds. The seeds were arranged in a single layer on an aluminum surface, inside transparent plastic germination boxes with lids $(11 \times 11 \times 3 \mathrm{~cm})$ and $40 \mathrm{~mL}$ of distilled water under the screen, and kept in biochemical demand oxygen (B.O.D.) chamber for 24, 48, 72, 96 and 120 hours, along with seeds that were not submitted to the AA (0 h).
Moisture content was determined before and after the AA, by drying seeds at $105 \pm 3^{\circ} \mathrm{C} / 24$ h (Brasil, 2009) in two replicates of 20 seeds for each treatment.

Germination test: after each aging period, the seeds were lightly rinsed in running water for two minutes due to the incidence of fungi and then submitted to germination in a B.O.D. chamber, at $25^{\circ} \mathrm{C}$ and photoperiod of $8 \mathrm{~h}$, inside transparent plastic boxes. The seeds were placed on two sheets of filter paper and covered with another sheet. The substrate was moistened with distilled water equivalent to 2.5 times the mass of the non-hydrated paper. Primary root emission with positive geotropic curvature was adopted as the germination criterion. The counts were made daily over 21 days.

Healthy seedlings: at 21 days after planting, the normal seedlings of each repetition and each treatment were counted, according to Brazilian criteria (2009).

The germination speed index was determined based on daily counts of the number of germinated seeds, from the first to the 21st day after planting, using the methodology proposed by Maguire (1962).

Moisture content data were not submitted to analysis of variance. The behavior of each sublot (treatment) during the aging period was analyzed by up to $3^{\text {rd }}$ degree polynomial regression, selecting the highest degree equation with statistical significance at 5\% using the F-test.

Because of the negative estimates that occurred in some sub-lots for the traits evaluated, the data of these treatments were analyzed in Origin 6.0 graphing software, using a nonlinear logistic model, according to the methodology proposed by Pôrto et al. (2006), who adopted a logistics 1 model:

$$
y=\frac{a}{1+e^{-k(x-x c)}}
$$

where: $y=$ characteristic value for a given value of $\mathrm{x}$ (aging time); $\mathrm{a}=$ maximum value of trait $\mathrm{y}$; $\mathrm{e}$ $=$ Napierian logarithm base, $\mathrm{k}=$ relative growth rate (of $y$ reduction in the present case); $\mathrm{xc}=\mathrm{x}$ value (aging time), which reduces the maximum value of the trait by $50 \%$ and corresponds to the aging time at the inflection point of the curve. Statistical analyses were processed in ESTAT/Jaboticabal software and Microcal Origin 6.0 .

\section{Results and Discussion}

The moisture content of the treatments, resulting from seed classification related to color 
and size, before and after AA, is shown in Figures 1 and 2. The initial moisture content of lightcolored seeds (Figure 1) ranged between 12 and $13 \%$ and increased after AA up to $96 \mathrm{~h}$ for seeds retained in sieves 11,12 , and 13 and up to $120 \mathrm{~h}$ for sieves 14 and 15 . The initial content of darkcolored seeds (Figure 2) varied between 11 and $13 \%$, increasing after accelerated aging up to $96 \mathrm{~h}$.

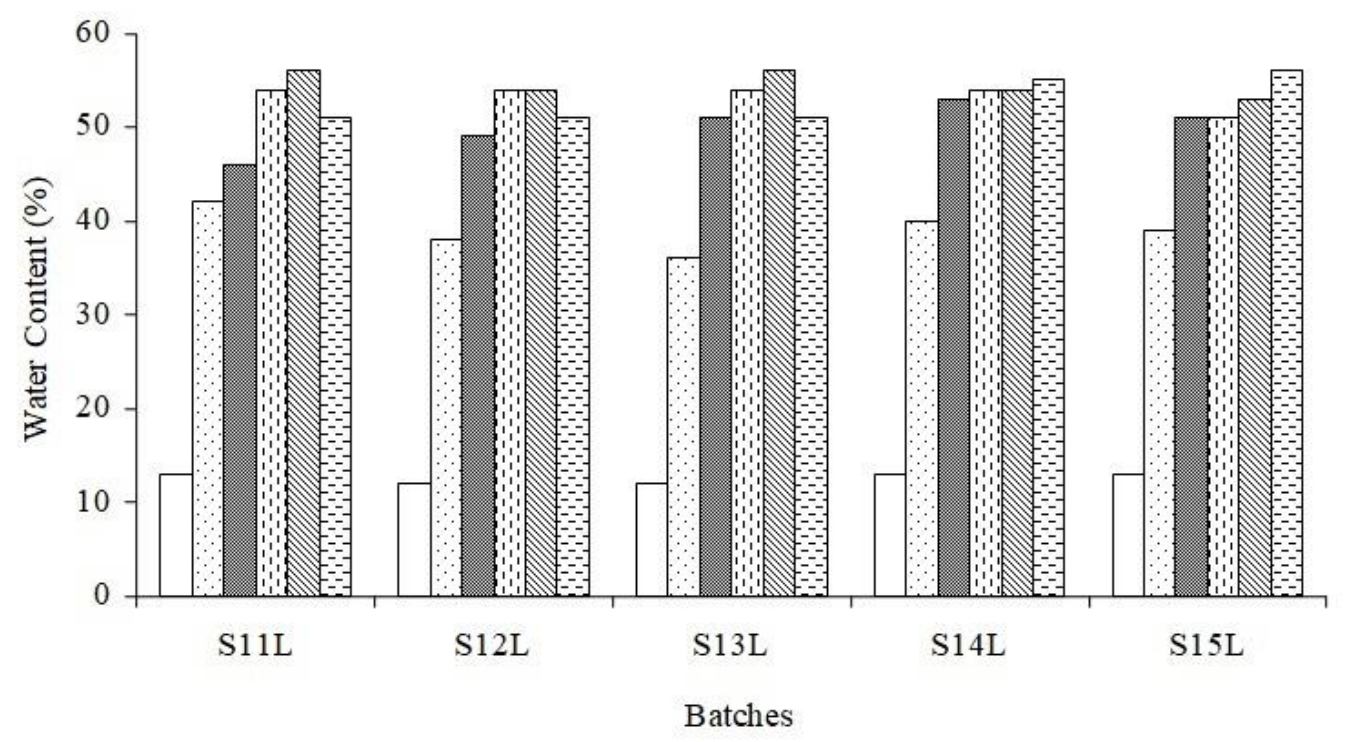

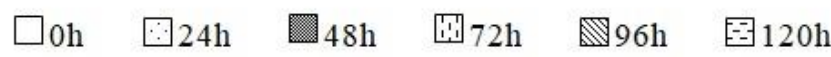

Figure 1. Moisture content (\%) of light-colored Piptadenia moniliformis Benth. seeds (L) classified in different-sized sieves (S11, S12, S13, S14, and S15), before and after accelerated aging at $45^{\circ} \mathrm{C}$. Font: Azerêdo \& Paula (2020).

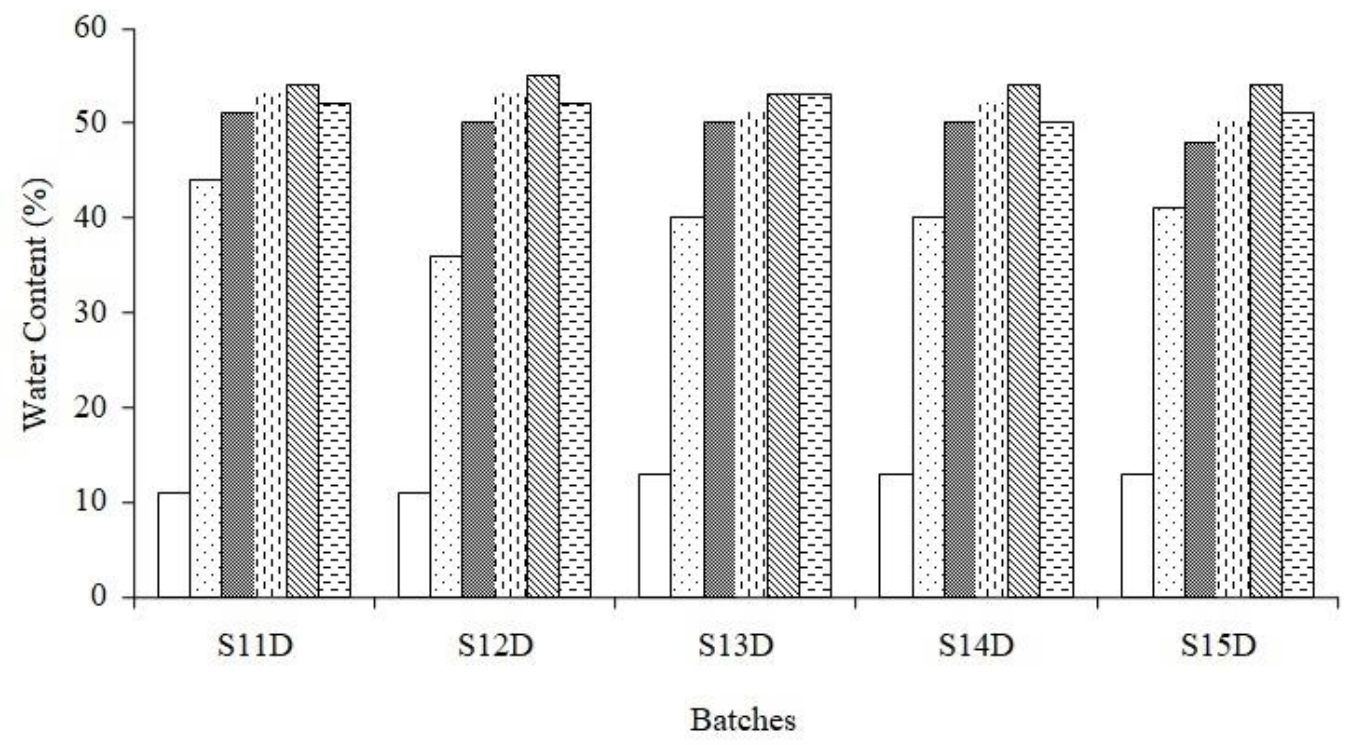

$\square 0 \mathrm{~h} \quad \square 24 \mathrm{~h} \quad \square 48 \mathrm{~h} \quad$ 四72h $\quad \mathbb{Q} 96 \mathrm{~h} \quad$ 园 $120 \mathrm{~h}$

Figure 2. Moisture content (\%) of dark-colored Piptadenia moniliformis Benth. seeds (D) classified in different-sized sieves (S11, S12, S13, S14, and S15), before and after accelerated aging at $45^{\circ} \mathrm{C}$. Font: Azerêdo \& Paula (2020).

After AA for $24 \mathrm{~h}$, the moisture content for all treatments was higher than $35 \%$. Moisture content increased up to $96 \mathrm{~h}$ of aging, reaching values above $50 \%$, and in some sub-lots, increased up to $120 \mathrm{~h}$. 
The increase in seed moisture content was higher after $24 \mathrm{~h}$ of aging for all treatments. Although moisture content also rose after other aging time, the increase was non-significant.

In terms of moisture content, several species' seeds can behave differently depending on the aging time and temperature. The moisture contents of the different treatments were relatively high (greater than $50 \%$ after $96 \mathrm{~h}$ of AA), when compared to other studies. Thus, seed moisture content stabilization in the AA test depends on the species under study.

Tabernaemontana fuchsiaefolia A. DC. seeds (Moraes et al., 2016), for example, showed a rise in moisture content after the aging periods, using the traditional method. Similarly, Carvalho et al. (2016) showed a considerable increase in mahogany seeds' moisture content after the AA test. These increases were observed mainly in the first $24 \mathrm{~h}$, when moisture content nearly doubled at the two highest temperatures tested (43 and

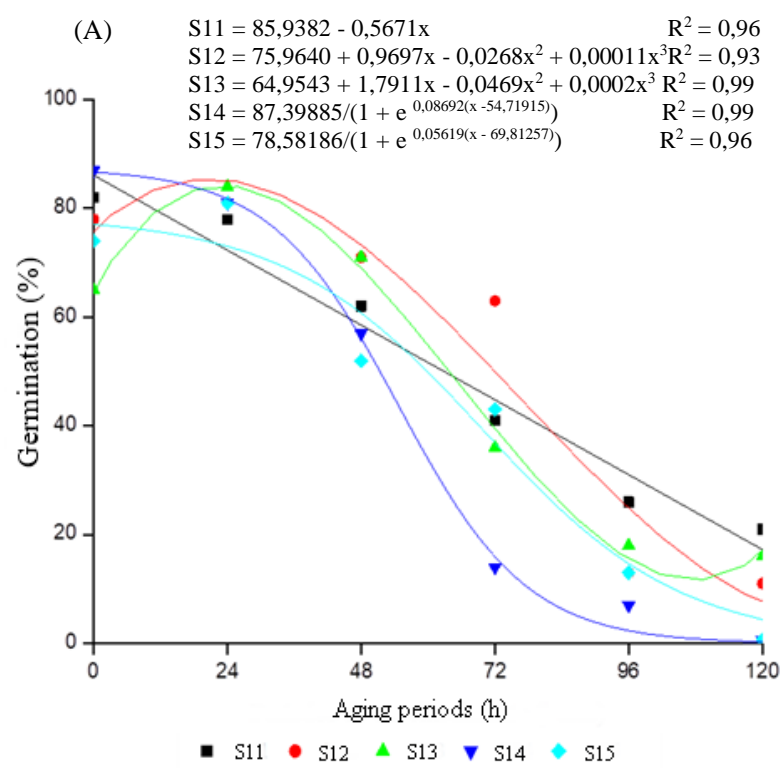

$45^{\circ} \mathrm{C}$ ). In Mabea fistulifera Mart. seeds, AA showed a marked increase in seed moisture after $24 \mathrm{~h}$ of aging using the traditional method. The initial seed moisture content of $12.6 \%$ rose to $21.5 \%$, remaining nearly constant after this period, reaching $23.96 \%$ after $96 \mathrm{~h}$ of accelerated aging, at all temperatures tested $\left(41,43\right.$ and $\left.45^{\circ} \mathrm{C}\right)$ (Gomes Júnior \& Lopes, 2017).

A slight increase in germination was observed for some treatments after $24 \mathrm{~h}$ of AA at $45^{\circ} \mathrm{C}$. This rise was not found only for lightcolored seeds from sieves 11, 14, and 15 (Figure $3 \mathrm{~A})$ and dark seeds from sieve 11 (Figure 3B). At the end of $120 \mathrm{~h}$ of AA, the light-colored seeds from sieve 14 did not germinate, and the highest germination values were observed in sieves 11 and 13 (Figure $3 \mathrm{~A}$ ).

The dark seeds showed a decline in germination (Figure 3B) from $48 \mathrm{~h}$ of $\mathrm{AA}$ onwards, albeit not as pronounced as observed in light-colored seeds (Figure 3A).

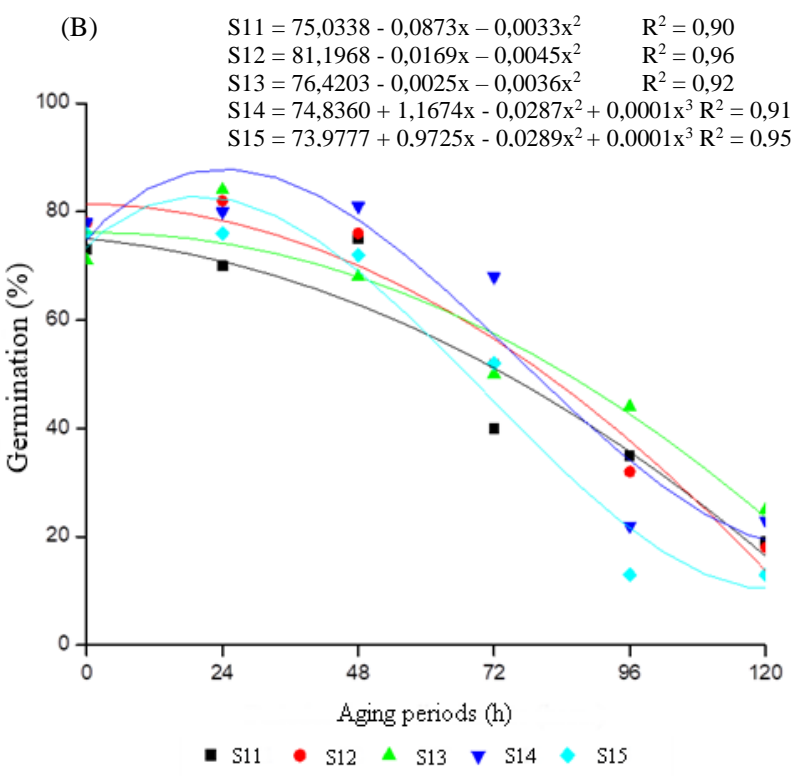

Figure 3. Germination (arccosene $\sqrt{G / 100}$ ) of light (A) and dark-colored (B) Piptadenia moniliformis Benth. seeds of different sizes (sieves 11, 12, 13, 14, and 15: S11, S12, S13, S14, and S15, respectively), after accelerated aging at $45^{\circ} \mathrm{C}$, for different periods. Font: Azerêdo \& Paula (2020).

The slight increase in Piptadenia seed germination after $24 \mathrm{~h}$ of $\mathrm{AA}$ at $45^{\circ} \mathrm{C}$ can be attributed to the increase in moisture content after aging, due to the conditions promoted by AA (high RH and temperature), which activated seed metabolism. These seeds would likely have already started germinating with water addition because of the three-phase pattern of water absorption (Bewley \& Black, 1994).

Germination declined for all treatments, regardless of seed size or color (Figures 3A; 3B). The dark-colored seeds (Figure 3B) exhibited a decline from $48 \mathrm{~h}$ of AA onwards, but not as marked as observed in their light-colored counterparts (Figure 3A). The difference in vigor of dark-colored seeds is also not as evident as in those with lighter coloring, where the regression curves are closer in the former (Figure 3A) than the latter (Figure 3B), in which size classification may not be essential.

Gomes Júnior \& Lopes (2017) conducted the traditional, accelerated aging test in saline solution with Mabea fistulifera Mart. seeds, at different temperatures and aging times, found a 
significant reduction in germination. In Leucaena leucocephala seeds, germination declined in the different lots, increasing the accelerated aging time (Araújo et al., 2017). Considering three $P$. moniliformis seed lots, Aquino et al. (2018) concluded that aging for $24 \mathrm{~h}$ at $41^{\circ} \mathrm{C}$ was the most appropriate condition to separate seed lots into different vigor levels since it produced results similar to those obtained when classifying the initial quality of the lots.

Mulungu (Erythrina velutina Will.) seeds aged $24,48,72$, and $96 \mathrm{~h}$ at 41 and $45^{\circ} \mathrm{C}$ exhibited reduced viability and vigor (Guedes et al., 2009). These results agree with those obtained in the present study with $P$. moniliformis seeds, in which 24 hours of aging did not promote a significant change in the germination of Piptadenia seeds compared to controls (nonaged seeds), but with a progressive decrease starting at $48 \mathrm{~h}$ of aging; the $120 \mathrm{~h}$ period did not wholly inhibit Piptadenia seed germination.

According to Marcos Filho (2015), enzymes such as catalase, dehydrogenase, and glutamic acid decarboxylase decrease during the deterioration process, thereby causing a decline in

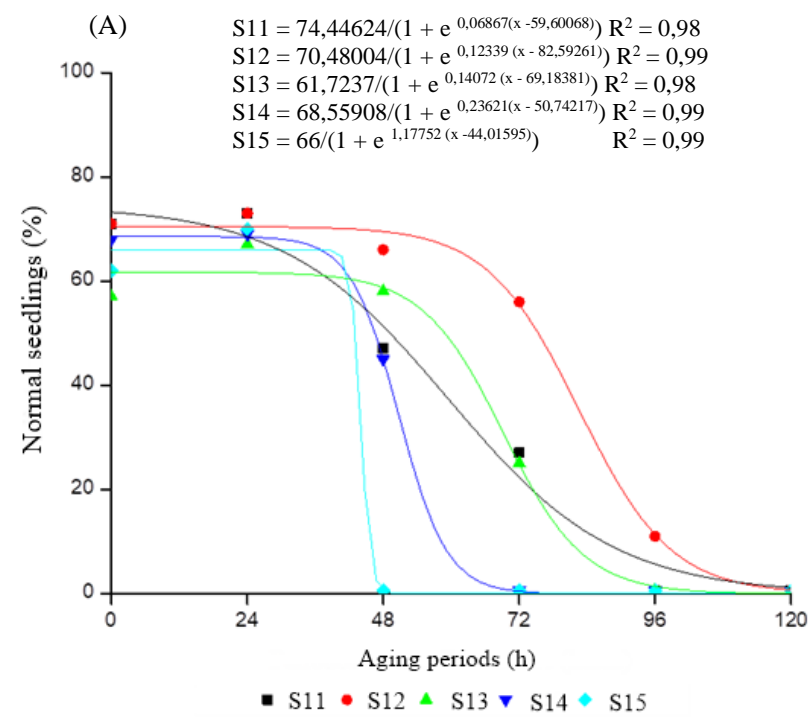

the energy supply to the germinating seed, given that changes in the enzyme structure contribute to reducing their efficiency.

The stress conditions imposed by the AA test increase seeds' metabolic activity and consume their reserves faster (Bewley and Black, 1994). Also, the disorganized membrane system makes them more susceptible to the harmful effects of $\mathrm{O}_{2}$ that cause compound oxidation and enzyme activation (Ferreira et al., 2004), resulting in a gradual drop in germination and vigor. These events may be related to the reduced germination capacity of Piptadenia seeds after $48 \mathrm{~h}$ of AA. The lower percentage of normal seedlings (NS) was more pronounced for light-colored seeds (Figure 4A) than their dark-colored counterparts (Figure 4B). There was no NS formation in lightcolored seeds from sieves 13,14 , and 15 after 48 , 24 , and $72 \mathrm{~h}$ of aging, respectively. The dark seeds from sieves 14 and 15 (Figure 4B) showed higher NS values up to $48 \mathrm{~h}$ of aging with a $50 \%$ decline after $72 \mathrm{~h}$ and no NS formation after 96 and $120 \mathrm{~h}$. For dark seeds from sieves 11, 12, and 13 , NS production decreased less than AA times.

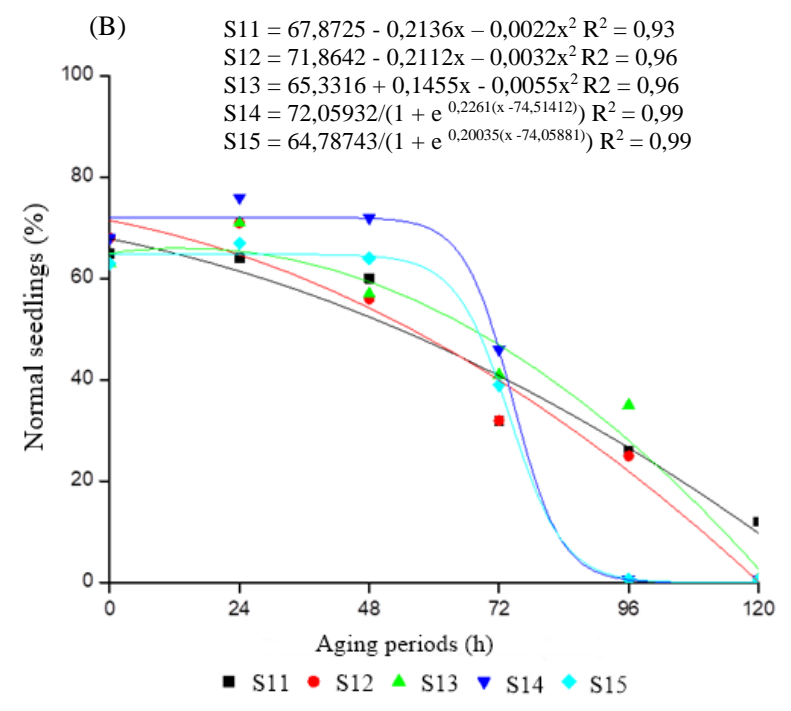

Figure 4. Normal seedlings (arccosine $\sqrt{G / 100}$ ) obtained from light (A) and dark-colored (B) Piptadenia moniliformis Benth. seeds of different sizes (sieves 11, 12, 13, 14 and 15: S11, S12, S13, S14, and S15, respectively), after accelerated aging at $45^{\circ} \mathrm{C}$, for different time periods. Font: Azerêdo \& Paula (2020).

Relating to the number of NS, dark seeds were more vigorous than light-colored seeds, especially sizes 13,14 , and 15 . Vigorous seeds exhibit greater germination capacity (Figure 4A) and produce NS after being submitted to AA stress, while those with less vigor display significantly lower germination (Marcos Filho, 2015).

Carvalho et al. (2016) found that increased exposure to higher temperatures may result in more marked deterioration of the integument and cell membranes of mahogany seeds submitted to accelerated aging concerning seeds not early aged or aged at milder temperatures ( 39 and $41^{\circ} \mathrm{C}$ ).

According to França-Neto \& Krzyzanowski (2018), before the total loss of germination capacity after accelerated aging, a sequence of biochemical changes are triggered, starting with membrane degradation, resulting in a 
decrease in germination speed, seedling emergence, and an increase in abnormal seedlings. Seed vigor, evaluated by the germination speed index (GSI), also declined for all treatments, regardless of color and size. For the light-colored seeds (Figure 5A), those retained in sieve 11 (S11) exhibited quadratic behavior; those of S12 were fit to a cubic model and the others to nonlinear equations. Comparing GSI results

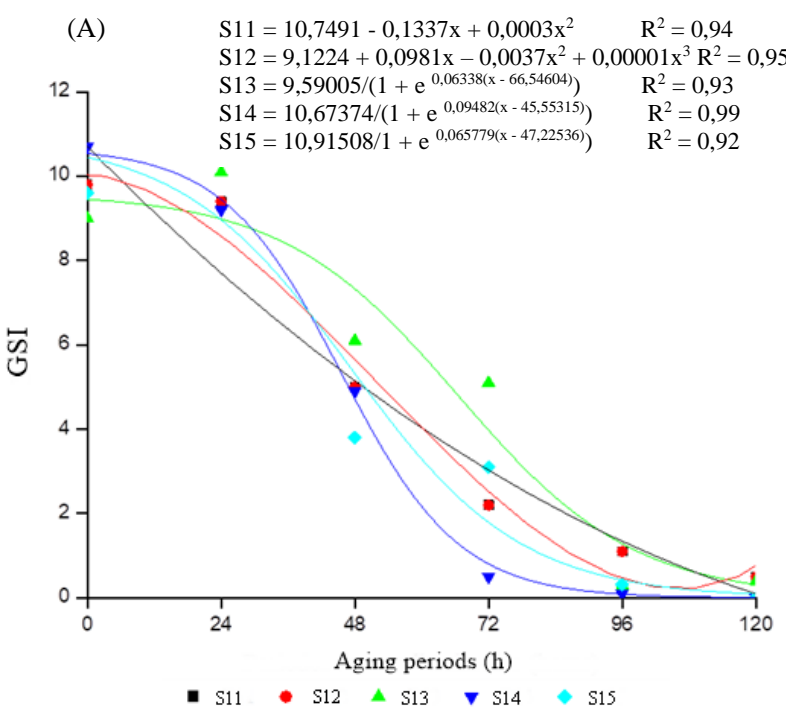

(Figures 5A and $\mathrm{B}$ ) with germination (Figures 3A and $\mathrm{B}$ ) shows GSI decreases before germination over the AA times, in a more pronounced manner in light-colored seeds, from $24 \mathrm{~h}$ onwards. Except for sieve 13 (Figure 5B), whose behavior was linear (decreasing), the other sub-lots of darkcolored seeds fit to a cubic model better than their light-colored counterparts over the AA times.

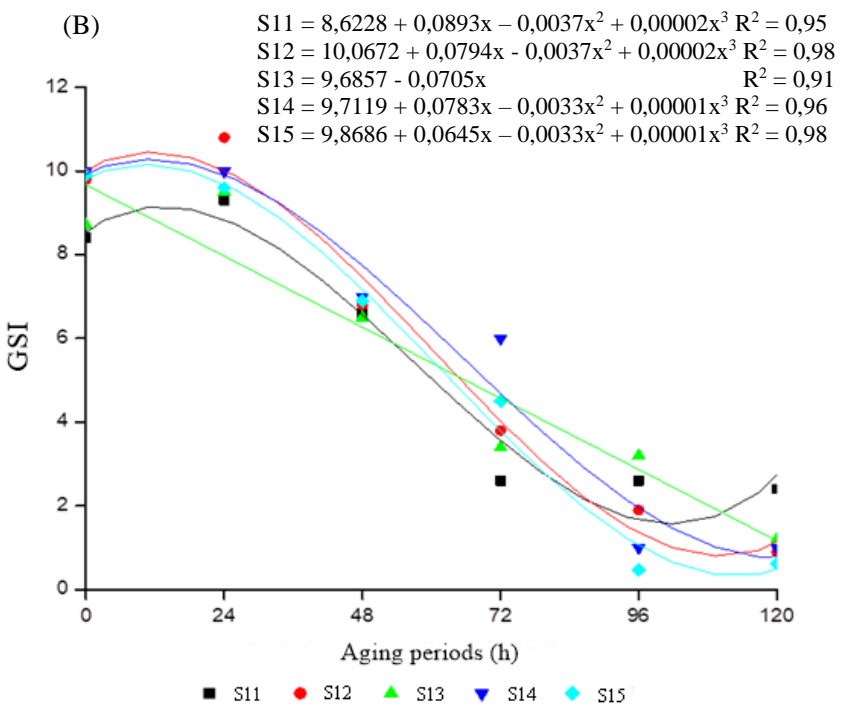

Figure 5. Germination speed index of light (A) and dark-colored (B) Piptadenia moniliformis Benth. seeds of different sizes (sieves 11, 12, 13, 14 and 15: S11, S12, S13, S14, and S15, respectively), after accelerated aging at $45^{\circ} \mathrm{C}$, for different periods. Font: Azerêdo \& Paula (2020).

GSI-assessed vigor decreased for all treatments, regardless of seed color and size. However, for light-colored seeds, this decrease was much more pronounced after $24 \mathrm{~h}$ of aging.

Accelerated aging hastens seed deterioration, whose symptoms can be observed during germination and the initial phases of seedling development. Among the most evident manifestations are reduced germination speed and capacity in laboratory conditions and slower seedling emergence and growth (Marcos Filho, 2015). According to Lima et al. (2015), the aging test, accelerated by the traditional method, was useful in classifying Crambe seeds batches concerning their physiological quality. It was observed that the longer the seed exposure to AA, the faster the deterioration rate. The light-colored seeds were more sensitive to the stress caused by the AA, especially sizes 14 and 15 . Before aging, the initial quality of sub-lot seeds (light and dark colors) was high and similar, making it impossible to differentiate between them with the germination test because it is conducted under favorable conditions, causing the seed lots to reveal their full germination potential. When the sub-lots were submitted to the AA test, at high humidity and temperatures, slight and marked differences were detected between them, demonstrating their good performance or not in the field, where seeds are exposed to different environmental conditions.

The low vigor exhibited by light-colored seeds belonging to sieves 14 and 15 is likely related to the ripening process, which may not have terminated satisfactorily, thereby causing reduced vigor. After $48 \mathrm{~h}$ of aging, there were differences between the sub-lots and a significant decrease in the evaluated traits, indicating that the seeds could no longer repair the damage caused by exposure to high humidity and temperature, culminating in the total loss of germination capacity, which is the final effect of deterioration (Binotti et al., 2008).

For some sub-lots, 96 and $120 \mathrm{~h}$ of aging were highly damaging, leading to total or almost total germination capacity loss. During these periods, there was high water absorption and fungi, which probably contributed to the decline in physiological seed quality. The occurrence of fungi after accelerated aging was also reported by Moraes et al. (2016), in T. fuchsiaefolia seeds, and Duarte et al. (2017), in watermelon seeds, whose 
reduced viability was attributed to contamination by pathogenic microorganisms, as a consequence of AA, causing decreased seed vigor.

\section{Conclusion}

The accelerated aging test carried out at $45^{\circ} \mathrm{C}$ for $72 \mathrm{~h}$ is efficient in evaluating the seed quality of Piptadenia moniliformis Benth., regardless of seed color and size.

\section{References}

Amaro, H. T. R.; David, A. M. S. S.; Silva Neta, I. C.; Assis, M. O.; Araújo, E. F.; Araújo, R. F. 2014. Teste de envelhecimento acelerado em sementes de crambe (Crambe abyssinica Hochst), cultivar FMS Brilhante. Revista Ceres, 61, (2), 202-208. DOI: 10.1590/S0034-737X2014000200007

AOSA. 1983. Association of Official Seed Analysis. Seed vigour handbook. In: AOSA. The handbook of seed testing. East Lansing, 88p. (Contribuition, 32).

Aquino, G. S. M.; Benedito, C. P.; Pereira, K. T. O.; Santos, P. C. S.; Oliveira, J. C. D. 2018. Accelerated aging of Piptadenia moniliformis (Benth.) seeds. Revista Caatinga, 31, (3), 681-686. DOI: 10.1590/1983-21252018v31n317rc

Araújo, F. S.; Félix, F. C.; Ferrari, C. S.; Bruno, R. L. A.; Pacheco, M. V. 2017. Adequação do teste de envelhecimento acelerado para avaliação do vigor de sementes de leucena. Revista Brasileira de Ciências Agrárias, 12, (1), 92-97. DOI: 10.5039/agraria.v12i1a542

Azeredo, G. A. de; Paula, R. C. de; Valeri, S. V. 2010. Superação de dormência de sementes de Piptadenia moniliformis Benth. Revista Brasileira de Sementes, 32, (2), 49-58. DOI: 10.1590/S0101-31222010000200006

Bewley, J. D.; Black, M. 1994. Seeds: physiology of development and germination. New York: Prenum Press, 445p.

Brasil. 2009. Ministério da Agricultura e Reforma Agrária. Regras para Análise de Sementes. Brasília: SNDA/DNDV CLAV, 365p.

Binotti, F. F. S.; Haga, K. I.; Cardoso, D.; Alves, C. Z.; Sá, M. E.; Arf, O. 2008. Efeito do período de envelhecimento acelerado no teste de condutividade elétrica e na qualidade fisiológica de sementes de feijão. Scientarum Agronomia, 30, (2), 247-254. DOI: $10.1590 / \mathrm{S} 1807-86212008000200014$

Carvalho, C. A.; Silva, J. B.; Alves, C. Z. 2016. Envelhecimento acelerado em sementes de mogno. Revista Ciência Agronômica, 47, (4), 691-699. DOI: $10.5935 / 1806-$ 6690.20160083
Delouche, J. C.; Baskin, C. C. 1973. Accelerated aging techniques for predicting the relative storability of seed lots. Seed Science and Technology, 1, (2), 247-452.

Duarte, R. R.; Borges, R. S.; Costa, G. G. S.; Silva, E. M.; Santos, J. M. 2017. Envelhecimento acelerado tradicional e alternativo em sementes de melancia. Journal of Neotropical Agriculture, 4, (5), 119-123. DOI: 10.32404/rean.v4i5.2207

Ferreira, A. R.; Oliveira, L. M.; Carvalho, D. de; Oliveira, A. F. de; Gemaque, R. C. R. 2004. Qualidade fisiológica de sementes de Copaifera langsdorffii envelhecidas artificialmente. Revista Ciência Agronômica, $35,(1), 82-86$.

França-Neto, J. B.; Krzyzanowski, F. C. 2018. O vigor e o desempenho das sementes. Embrapa Soja-Artigo de divulgação na mídia (INFOTECA-E). Available at: http://www.infoteca.cnptia.embrapa.br/infote ca/handle/doc/1107330. Access at: 10 Mar. 2020.

Guareschi, D. G.; Lanzarini, A. C.; Lazarotto, M.; Gonzatto, C.; Barbieri, G. 2015. Envelhecimento acelerado de sementes e qualidade de plântulas de Bauhinia forficata Link em diferentes substratos e tamanhos de tubetes. Revista Agro@mbiente On-line, 9, (1), 65-71. DOI: 10.18227/19828470ragro.v9i1.2175

Gomes Júnior, D.; Lopes; J. C. 2017. Teste de envelhecimento acelerado para avaliar o potencial fisiológico de sementes de canudode-pito. Ciência Florestal, 27, (4), 11051115.

Guedes, R. S.; Alves, E. U.; Gonçalves, E. P.; Viana, J. S.; Bruno, R de L. A.; Colares, P. N. 2009. Resposta fisiológica de sementes de Erythrina velutina Willd. ao envelhecimento acelerado. Semina: Ciências Agrárias, Londrina, 30, (2), 323- 330.

Lima, C. R.; Bruno, R. L.; Silva, K. R. G.; Pacheco, M. V.; Alves, E. U. 2014. Qualidade fisiológica de sementes de diferentes árvores matrizes de Poincianella pyramidalis (Tul.) L. P. Queiroz. Revista Ciência Agronômica, 45, (2), 370-378.

Maguire, J. D. 1962. Speed of germination - aid in selection and evaluation for seedling emergence and vigor. Crop Science, 2, 176177.

Maia, G. N. 2004. Caatinga: árvores e arbustos e suas utilidades. 1. ed. São Paulo: D\&Z Computação Gráfica e Editora, 413p. 
Marcos Filho, J. 2015. Fisiologia de sementes de plantas cultivadas. Piracicaba: FEALQ, 660p. il.

Matos, A. C. B.; Lima, E. E.; Silva, L. J. 2015. Fisiologia da germinação de sementes de Dalbergia nigra (Vell.) Allemão ex Benth. sob diferentes temperaturas e tempos de exposição. Revista Árvore, 39, (1), 115-125. DOI: 10.1590/0100-67622015000100011

Menezes, V. O.; Lopes, S. J.; Tedesco, S. B.; Henning, F. A.; Zen, H. D.; Mertz, L. M. 2014. Cytogenetic analysis of wheat seeds submitted to artificial aging stress. Journal of Seed Science, 36, (1), 71-78. DOI: 10.1590/S2317-15372014000100009

Moraes, C. E.; Lopes, J. C.; Farias, C. C. M.; Maciel, K. S. 2016. Qualidade fisiológica de sementes de Tabernaemontana fuchsiaefolia A. DC em função do teste de envelhecimento acelerado. Ciência florestal, 26, (1), 213-223. DOI: 10.5902/1980509821114

Padilha, M. S.; Oliveira, A. S. M.; Sobral, L. S. 2018. Teste de envelhecimento acelerado em sementes de Peltophorum dubium Sprengel Taubert. Revista Thema, 15, (3), 1115-1122. DOI: $\quad$ 10.15536/thema.15.2018.11151122.883.

Pôrto, D. R. D. Q.; Cecílio Filho, A. B.; May, A.; Barbosa, J. C. 2006. Acúmulo de macronutrientes pela cebola 'Optima' estabelecida por semeadura direta. Horticultura Brasileira, 24, (4), 470-475. DOI: $\quad 10.1590 / \mathrm{S} 0102-05362006000400015$ 